\title{
Virtual Health Library in Nursing for Colombia: a New Scientific Communication Portal
}

Wilson Cañon-Montañez ${ }^{1,2}$

Scientific communication is understood as a set of socially shared dynamic processes and efforts, through which scientific knowledge is created, shared, and used. These processes also offer means and conditions for social interaction among the members of scientific communities, contributing to the production, dissemination, and use of knowledge and, consequently, to the advancement of science. (1) With technological progress, new tools have emerged from communication and information technologies (CIT) to disseminate scientific knowledge. The Virtual Health Library in Nursing (VHL in Nursing) is part of these new scenarios as thematic cooperation network and is an initiative from the region of IberoAmerica, which seeks to promote access to scientific information on nursing and establish alliances to maximize the shared use of CIT and collections of sources of information in Nursing. ${ }^{(2)}$
The VHL in Nursing, created in 2012, is coordinated by the School of Nursing at Brazil's Universidade Federal de Minas Gerais and supported by the Latin American and Caribbean Center on Health Information (BIREME), the Pan-American Health Organization (PAHO), World Health Organization (WHO), among other institutions. This international thematic collaborative network originated in Brazil and then other countries in the region (Argentina, Uruguay, Cuba, and Bolivia) joined the initiative to share nursing scientific information generated in each country. The work philosophy behind the $\mathrm{VHL}$ in Nursing to synthesize the process of scientific communication in Nursing involves the following activities: a) mapping of sources of information; b) identifying the strategies that enable the recovery or acquisition of the knowledge produced; c) storage or organization of knowledge; d) share communication and

1 RN, MSc, Ph.D. Coordinator Virtual Health Library in Nursing, Colombia. Professor, Faculty of Health Sciences, Universidad de Santander, Bucaramanga, Colombia. email: wcanon@udes.edu.co

2 Postdoctoral Researcher. Faculty of Medicine, Graduate Program in Epidemiology, Universidade Federal do Rio Grande do Sul, Porto Alegre, Brazil.

How to cite this article: Cañon-Montañez W. Virtual Health Library in Nursing for Colombia: a New Scientific Communication Portal. Invest. Educ. Enferm. 2017; 35(3): 257-259 
dissemination media and strategies; and e) outline cooperation strategies to create scientific research and enhance sources of information in Nursing. ${ }^{(3,4)}$

Colombia is an important country in the region on scientific production in Nursing. It has scientific journals in Nursing indexed in internationally recognized databases and bibliographic indexes.

(5) Additionally, it has several graduate programs in Nursing (Masters and PhD), some with high academic quality accreditation. It also has diverse libraries and cooperation centers that are part of the general VHL Network coordinated by BIREME/ $\mathrm{PAHO} / \mathrm{WHO}$. In relation to antecedents for the creation and implementation in Colombia of a virtual library on Nursing, in previous years some Colombian university institutions showed interest in the initiative, but it was not until 2015 that the project was readdressed and led during a meeting of the Regional Network for VHL in Nursing within the framework of the 13th Ibero-American Conference on Education in Nursing organized in the city of Rio de Janeiro by the Latin American Association of Nursing Schools and Faculties (ALADEFE). Thereafter, the project continued with support from the Coordination of the Regional Network for VHL in Nursing and BIREME/PAHO/ WHO and in 2016 the VHL in Nursing Colombia Portal implemented on the WordPress platform was officially launched. ${ }^{(6)}$

Said web portal provides unified access to all the scientific production in Nursing in Colombia related to articles, monographs, theses, dissertations, and indexed journals available in SciELO Colombia, LILACS, BDENF databases and the Rev@Enf collection. Furthermore, visitors and users of this new resource and virtual library will be familiarized with the graduate programs in Nursing and the principal lines of research in Nursing in Colombia, as well as other health education resources, national and international scientific and academic events, and link to the Regional Network for VHL in Nursing to learn of the research production on Nursing in countries in the region. The creation of the VHL in Nursing, Colombia is a significant achievement to promote the dissemination of scientific knowledge in Nursing in Colombia, showing visibility in the Regional Network for VHL in Nursing along with other member countries. The mission of the VHL in Nursing in Colombia is that of becoming a virtual patrimony and online resource of nursing information, easily accessed and driving processes of production, organization, and dissemination of the knowledge of all players involved in the generation of scientific and documentary information of nursing in Colombia.

The main objectives of the VHL in Nursing in Colombia are: a) strengthen the information networks in knowledge management and performance of the Nursing practice; b) generate conditions to explore, develop, broaden, consolidate, and strengthen cooperation networks and exchange of information on nursing in Colombia; c) review the current state of information resources on nursing, their processing, and flow, as well as the perspectives, possibilities, and proposals of institutional intervention or development, on the theme of nursing, to create cooperation networks through the national thematic VHL on Nursing; d) socialize and disseminate outcomes from nursing research projects, lines, and groups, as well as from directories of educational institutions and professional and scientific associations; and e) promote national autonomy for Nursing information management to support the development and articulation of the VHL in Nursing at country levels.

Some of the strategies used by the Coordination of the Regional Network for VHL in Nursing to promote continuous updating of information from the national VHLs on Nursing from member countries are through active participation in virtual and face-to-face meetings during the IberoAmerican Conferences on Nursing Education by ALADEFE and the Pan American Nursing Research Colloquium, supported by BIREME/ $\mathrm{PAHO} / \mathrm{WHO}$. These meetings are essential to establish interactions with the coordinators of the VHL on Nursing and learn of the difficulties, progress, and development strategies of each of the national virtual libraries. Within this context, it is necessary for the national VHLs on Nursing to work in cooperation with other scientific 
communication networks already consolidated or under development and which carry out activities for visibility and dissemination of scientific knowledge on Nursing: a) Ibero-American Council of Editors of Nursing and Related Journals; b) Rev@Enf - collection SciELO Nursing, international portal linked to the VHL in Nursing; Ibero-American Network of Scientific Editing on Nursing; c) International Forum of Nursing Journal Editors; and d) different national and international networks of editors of nursing scientific journals.

Lastly, it is worth highlighting that now that the VHL in Nursing in Colombia is a visible reality in the region, we expect this national web portal to consolidate itself as a tool for social appropriation of Nursing knowledge generated in the country. Nevertheless, although a big step has been taken, the project needs continuity by maintaining collaborative work and in network with national and international leaders who participate in the production and socialization of scientific knowledge on Nursing. ${ }^{(7)}$ All this, seeking to sensitize and mobilize institutions, scientific associations, health services, and other players involved in the generation of scientific knowledge to maintain the technical and policy sustainability necessary to disseminate, provide visibility, and protect the scientific heritage on Nursing in Colombia and, thus, contribute to improving the Nursing formation and practice to act with ethicalsocial commitment in the areas of education, research, and health care of the population. ${ }^{(8)}$

\section{References}

1. Leite FCL, Costa SMS. Gestão do conhecimento científico: proposta de um modelo conceitual com base em processos de comunicação científica. $\mathrm{Ci}$. Inf. 2007; 36(1):92-107.

2. Universidad Federal de Minais Gerais. Conferência Internacional de Comunicação Científica em Enfermagem. (Relatório final). Belo Horizonte: Universidade Federal de Minas Gerais, Escola de Enfermagem; 2015 [cited 18 Sep 2017]. Available from: http://bit.ly/2IldCVn

3. Lana FCF. Comunicación científica en Enfermería: importancia de las redes para la visibilidad y difusión del conocimiento. Enferm. Univ. 2017; 14(2):77-8.

4. Lana FCF. Scientific communication in nursing. Rev. Gaúcha Enferm. 2015; 36(3)10-1.

5. Silva RS. Pós-graduação e a pesquisa em enfermagem na América Latina: avanços e desafios. Rev. Cuid. 2015; 6(2): 1019-21.

6. Biblioteca Virtual en Salud Enfermería Colombia. [cited 18 Sep 2017]. Available from: http:// bvsenfermeria.bvsalud.org/colombia/

7. Williams GF, Cañon-Montañez W. International leadership in nursing. Rev. Cuid. 2013; 4(1): 433-6.

8. Cano-Serna DA, Correa-Bolívar NA, Flórez-Rendón WA, Giraldo-Giraldo YD, Monsalve-Cuervo MK, Restrepo-Otálvaro AF. Management of resources in nursing: beyond leadership. Our will to be and do. Invest. Educ. Enferm. 2013; 31(2): 315-8. 